\title{
北陸自動車道 大慶寺川橋での電気防食試験の評価
}

\author{
野村昌弘 ${ }^{* 1} \cdot$ 前田好裕 ${ }^{* 2} \cdot$ 石村勝則*3 ・平 俊勝*4
}

\begin{abstract}
概 要 北陸自動車道 大慶寺川橋では, 塩害対策として日本で最初に電気防食を道路橋に試験採用した経緯がある。 電気防食を実施してから 9 年経過した現在, コンクリート内部の鋼材は, 当該地区で推定した発錆限界塩化物イオン量 1.2 $\mathrm{kg} / \mathrm{m}^{3}$ を大きく上回る厳しい塩害環境にあるにもかかわらず腐食の進行が停止していた。また, 9 年間にわたり所定の復 極量 $100 \mathrm{mV}$ が確保され, 良好な防食状態にあったと考える。さらに陽極材の性能評価では, 外部電源方式で使用され たチタン系陽極材は, 全く健全であった。当初に計画した耐用年数 40 年は, 確保できるものと思われる。また, 流電陽 極方式の亜鉛陽極材は，コンクリート内部の鋼材密度ならびに腐食環境の違いにより消耗率が異なるが，おおむね今後 7 年間は機能を有するものと推測した。

キーワード 塩害, 電気防食
\end{abstract}

\section{1.はじめに}

北陸自動車道 大慶寺川橋は, 石川県松任市の日本海 沿岸から $80 \mathrm{~m}$ の所に位置し, 飛来塩分の影響を受ける $\mathrm{PC}$ ポストテンション単純 T げた橋（橋長 $26.05 \mathrm{~m}$ ) で ある。当橋は, 昭和 47 年に供用し, 11 年後の昭和 58 年 に第 1 回目の塩害補修（塗装）が行われた。その後，再 損傷が発生したため, 昭和 63 年に断面修復による応急 補修，平成元年に部分塗装補修および張出床版部分打 換, さらにPC ケーブルの破断が確認されたため外ケー ブルによる補強を実施するとともに，一部のけたに日本 の道路橋としては初めて電気防食による塩害対策を試験 的に実施した（写真 -1 , 写真 -2 )。

本稿では, 平成 10 年度に実施した電気防食部の現 況, 陽極材の性能評価ならびに 9 年間にわたる復極量と 防食電流の関係について取りまとめ, 電気防食の有効性

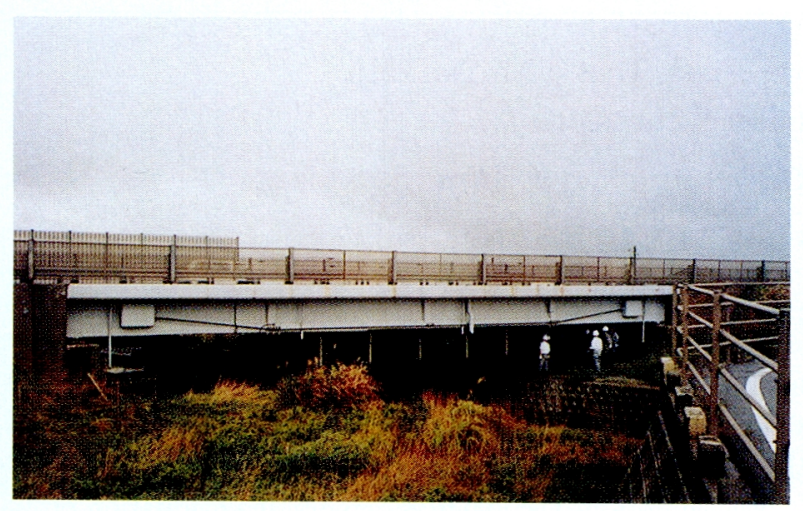

写真 -1 大慶寺川橋全景

\begin{tabular}{|c|c|}
\hline & $\begin{array}{l}1 \text { のむら・まさひろ/㹯クエストエンジニア 土木調查設計部土木 } \\
\text { 調杳設計課 主化 (正会亘) }\end{array}$ \\
\hline$* 2$ & $\begin{array}{l}\text { まえだ・よしひろ/飛島建設(㑣)土木事業本部 技術部 技術第二 } \\
\text { 課 課長 }\end{array}$ \\
\hline$* 3$ & $\begin{array}{l}\text { 3いしむら・かつのり／日本道路公団 北陸支社 小松管理事務所 } \\
\text { 改良助役 }\end{array}$ \\
\hline$* 4$ & 4 ひら・としかつ \\
\hline
\end{tabular}

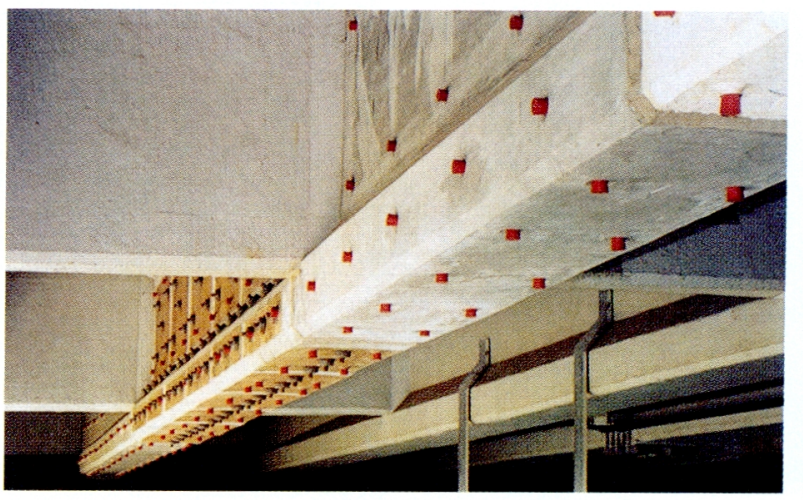

写真-2 電気防食による塩害補修

について報告するものである。

2. 電気防食の概要

電気防食は, 当時, 塩害損傷が著しかった下り線 $\mathrm{G}_{2}$ げた（海側から 2 番目のけた）で平成元年 11 月に施工 した。施工は, 図 2-1 に示すように，4 種類の電気防食 工法とコンクリート塗装のみを実施した非電気防食部が 同一条件で比較できるよう 5 ブロックに分割した。

電気防食の種類は, 外部電源方式 3 ケース, 流電陽極 方式 1 ケースの計 4 ケースである。この外部電源方式の うち 1 ケースは「部分電極方式」と称し，本橋で最初に 採用した工法である。各工法の概要は, 次のとおりであ る(図 2-2)。

（1）部分電極方式

部分電極方式は, 外部電源装置を用いて, コンクリー 卜面に一定間隔の溝を切り, その溝に白金めっきチタン 線を設置し, さらに導電性パテを充てんし, チタン線陽 極でコンクリート中の鋼材に防食電流を供給する工法 で，日本国内では本橋で新しく提案された工法である。

(2) 導電性塗料方式

導電性塗料方式は, 外部電源装置を用いて, 一次陽極 


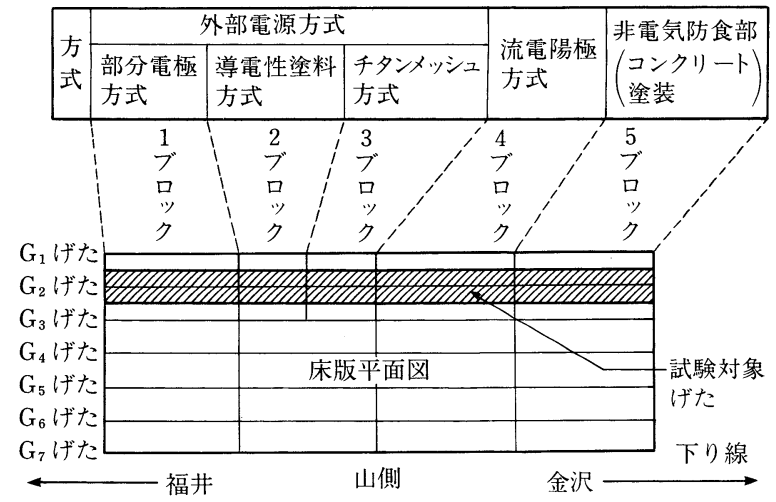

図 2-1 電気防食ブロック割付図

としてコンクリート面に $600 \mathrm{~mm}$ 間隔で白金めっきチ タン線を設置し，その上に二次陽極として導電性の塗料 を塗布，これらの陽極からコンクリート中の鋼材に防食 電流を供給する工法である。

(3) チタンメッシュ方式

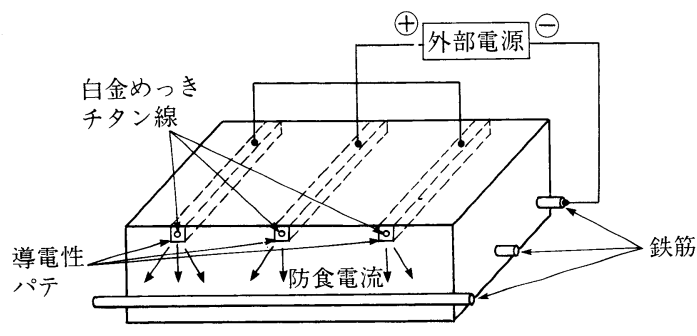

部分電極方式

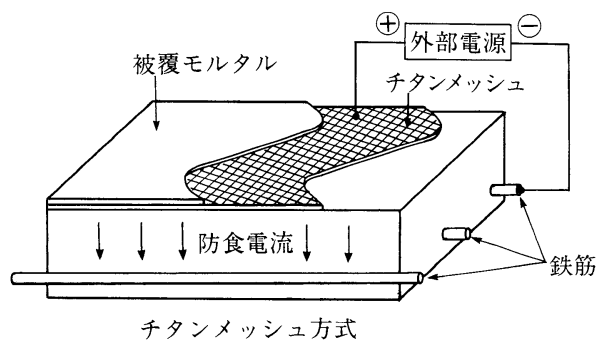

チタンメッシュ方式は, 外部電源装置を用いて, コン クリート面にチタンメッシュ陽極を固定し, その上を被 覆モルタルで覆い，このチタンメッシュ陽極からコンク リート中の鋼材に防食電流を供給する工法である。

（4）流電陽極方式

流電陽極方式は, 外部電源を必要としない。コンク リート面に亜鉛シート板を取付金具で固定し，この亜鉛 と鉄の金属的性質の違い（電位差）により，コンクリー ト中の鋼材に防食電流を供給する工法である。

3. 評 価

\section{1 含有塩分量}

電気防食部および非防食部において，含有塩分量調査 をブロックごとに実施した。試料は，コンクリート表面 から, 0 2 cm, 2〜 $4 \mathrm{~cm}$ の位置で採取した。塩化物イ オン量の分析結果は, 図 3-1 に示すとおりである。な

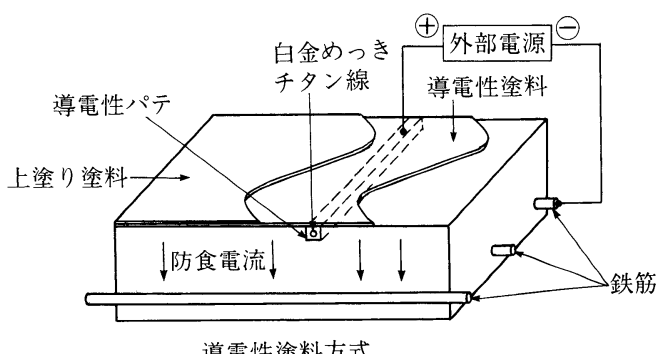

導電性塗料方式

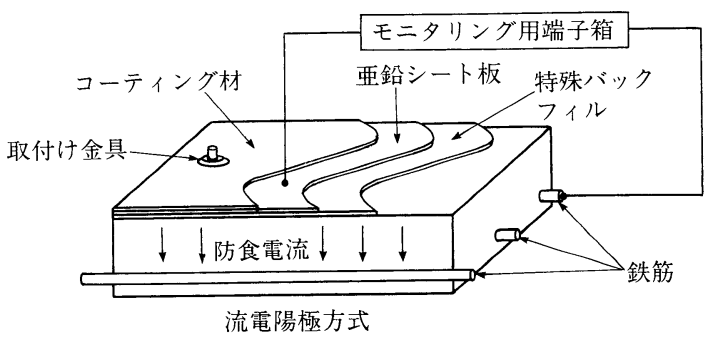

図 2-2 各種電気防食の概要図

Evaluation of Cathodic Protection Field Test with Daikeiji

River Bridge on Hokuriku Expressway

By M. Nomura, Y. Maeda, K. Ishimura and T. Hira

Concrete Journal, Vol. 37, No. 12, pp. 17 21, Dec. 1999

Synopsis In 1989 the Hokuriku expressway's Daikeiji River Bridge was given cathodic protection as a countermeasure for salt-induced corrosion. This was the first such case in Japan. In the nine years that have passed since cathodic protection was applied, corrosion of the steel reinforcements in the concrete has not progressed in spite of an environment with an amount of chloride much greater than $1.2 \mathrm{~kg} / \mathrm{m}^{3}$, the amount above which corrosion is presumed to be initiated. In addition, it is thought that effective conditions for corrosion protection have been maintained for nine years because the specified depolarization has been maintained at $100 \mathrm{mV}$. As for the evaluation of the performance of anode materials, titanium anodes, which were used in the impressed current cathodic protection system, were found to have no corrosion at all. Therefore it is presumed that the bridge's life span, initially estimated to be 40 years, will be attained. As for zinc sacrificial nodes in the galvanic cathodic protection system, they last approximately 7 years, although the consumption rate of the anodes differs depending on the steel density inside of the concrete and on the corrosive environment.

Keywords : salt-induced corrosion, cathodic protection 


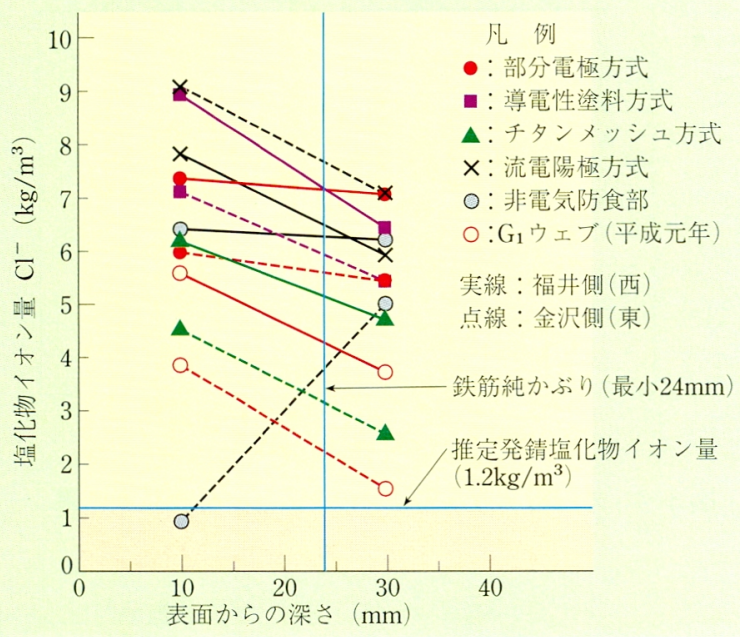

図 3-1 塩化物イオン量の分布状況

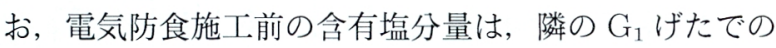
值であるが，鉄筋の純かぶり (最小 $24 \mathrm{~mm}$ ) 付近で, $2.2 \sim 4.4 \mathrm{~kg} / \mathrm{m}^{3}$ であった。今回 $\mathrm{G}_{2}$ けたでの調査結果 は，鉄筋の純かぶり付近で $3.0 \sim 7.7 \mathrm{~kg} / \mathrm{m}^{3}$ と当該地区 で推定した発錆限界塩化物イオン量 $1.2 \mathrm{~kg} / \mathrm{m}^{3}$ を大幅 に超えている1)。笽しい塩害環境が継続されているもの と思われる。

\section{2 復極量および防食電流の調査結果}

復極量および防食電流（流電陽極方式では発生電流） の経年変化を図 3-2 に示す。復極量とは, 通電中, 電 流を切った直後のコンクリート中の鋼材電位 (Instant-OFF 電位) と電流を切って約 24 時間経過した ときの鋼材電位 ( OFF 電位) との差をいう。本調査で は，各ブロック面ごとに電位計測点を設置している。図 3-2 の復極量は, これら計測点における電位の平均值で
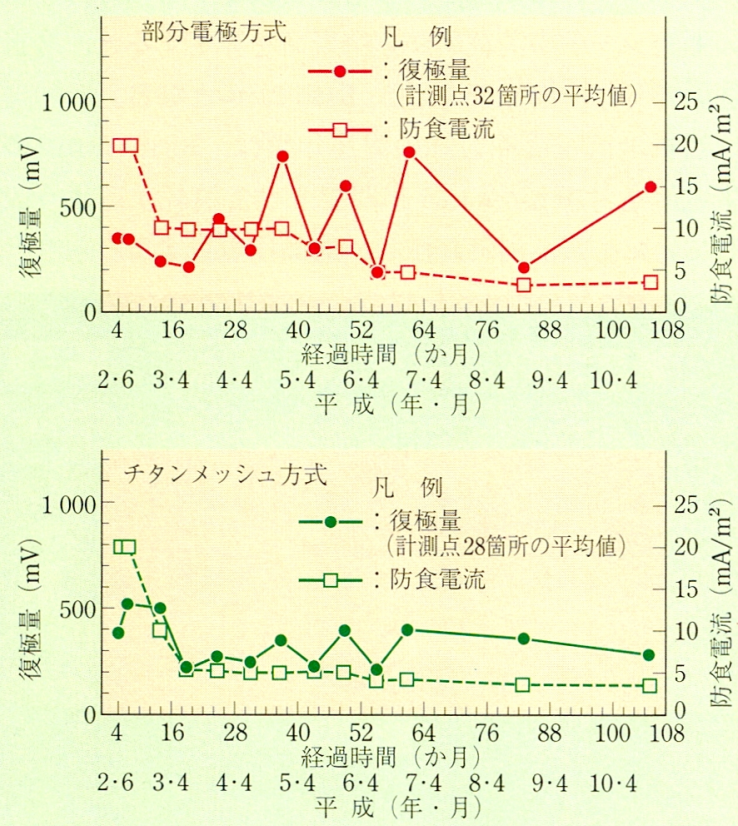

ある。また，防食電流とは，コンクリート表面に設置し た陽極材から内部の鋼材に対し，流れる電流のことであ る。

外部電源方式 (部分電極方式, 導電性塗料方式, チ夕 ンメッシュ方式）は, 設置当初, $20 \mathrm{~mA} / \mathrm{m}^{2}$ の防食電 流で通電した。しかし, 復極量が高めに推移したため, 水素脆化による $\mathrm{PC}$ 鋼材への影響を考慮し, 通電中, コ ンクリート内部における鋼材の電位を約 $-1000 \mathrm{mV}$ $(\mathrm{SCE})^{2)}$ より貴に，また経済性の面から鉄筋の良好な防 食状態を示す $100 \mathrm{mV}^{3}$ 以上を確保するよう順次低下さ せた。9 年間にわたる通電中は, 復極量が $100 \mathrm{mV}$ を確 保されており，良好な防食状態であったと考える。

一方, 流電陽極方式は, 異種金属間の電位差を利用し て防食電流を得る方式であり, 防食電流值（発生電流 値）の調整はできない。発生電流は，平成 2 年の測定時 $10.6 \mathrm{~mA} / \mathrm{m}^{2}$ をピークに除々に減少し, 平成 10 年の測 定時で発生電流が $1.0 \mathrm{~mA} / \mathrm{m}^{2}$ となった。この主な原因 としては，陽極材とコンクリート間の抵抗が大きく影響 (コンクリート中の水分の増加等) したものと推測され る。なお，復極量は $100 \mathrm{mV}$ 以上を確保されているこ とから，良好な防食状態にあるものと考える。

\section{3 非防食部の自然電位測定結果}

非防食部では, 継続的に自然電位を測定した。電気防 食施工当時の平成元年と平成 10 年の自然電位測定結果 を図 3-3に示す。なお, 計測は, 飽和カロメル電極 (SCE) を使用した。

平成元年の自然電位は, 大半が $-100 \mathrm{mV}$ 以下の領域 であるのに対し, 平成 10 年の測定結果では $-200 \mathrm{mV}$ の範囲が広がり, $-300 \mathrm{mV}$ 示す筒所も現れ, 全体的 に腐食傾向に進んでいるものと推測される。
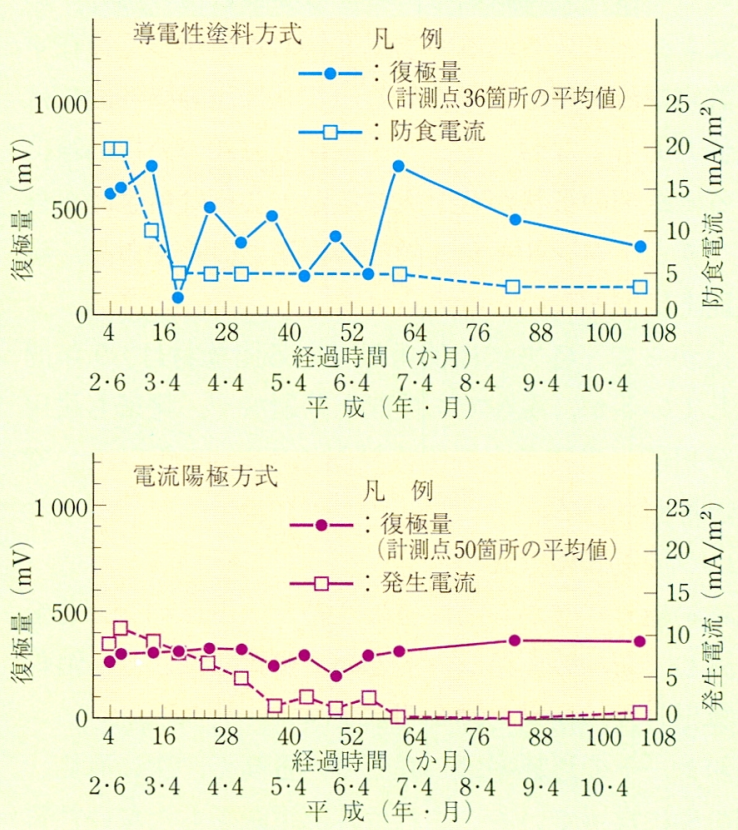

図 3-2 復極量および防食電流の経過 


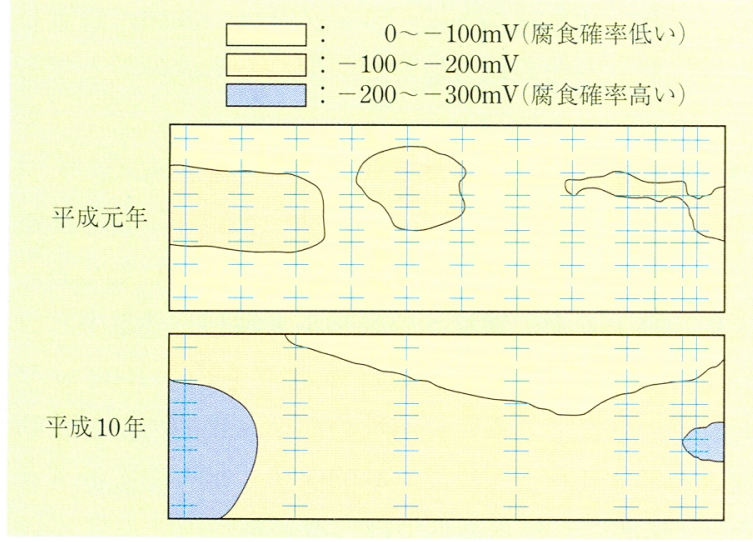

図 3-3 非防食部における自然電位測定結果

\section{4 陽極材の性能}

(1) 外部電源方式

部分電極方式, 導電性塗料方式およびチタンメッシュ 方式から陽極材を一部採取した。陽極材は，それぞれ， 白金めっきチタン線（導電性パテを含む），導電性塗料 （白金めっきチタン線を含む， チタンメッシュをオー バーレイ材ごとコアサンプリングし，新品の白金めっき チタン線との性能比較を行うため, アノード分極試験を 実施した。結果を図 3-4 に示す。

各方式のアノード分極曲線は, 同条件下で新品の白金 めっきチタン線のアノード分極曲線と比較すると, 低電 流密度側では直線的, 高電流密度側では分極曲線が立上 がるという基本的な曲線形状は一致している。ただし， 低電流密度時の直線部分の電位は, 新品の陽極に比較し て差が生じている。これは実橋から採取した陽極が通電 を行っていたことから陽極付近の $\mathrm{pH}$ が低くなったため と考える。また，陽極として使用可能な範囲（陽極電流 密度で 30 数 $\mathrm{mA} / \mathrm{m}^{2}$ ) の上限值である許容電流密度に 差があるのは，分極試験時における陽極近傍の水分が影 響したものと考えられる。陽極近傍の水分が多く存在す ると許容電流密度は大きくなる。これは, 陽極性能には 無関係である。なお, チタンメッシュ方式の分極曲線に おける直線部の形状が若干異なるが，これは白金めっき チタン線とチタンメッシュ陽極の構造上の差であり, 陽 極性能上は問題ないと考えられる。

したがって，各方式に使用している陽極材は，9年間 経過しているが, 現在でも性能上問題なく, 将来も耐用 は十分可能（当初予定の陽極材耐用年数 40 年以上）で あると推測される。

（2）流電陽極方式

流電陽極方式部から陽極材の亜鉛シート $(t=1 \mathrm{~mm})$ を 取り外し, 新品の亜鉛シートとの重量比較により, 消耗 率を算出した。結果を図 3-5 に示す。

亜鉛シートの消耗率は, 底面で一番高く, 次に海側, 山側の順になっている。これは外部電源をもたない性質 上, 鉄筋量が多い箇所, 腐食環境が厳しい箇所について

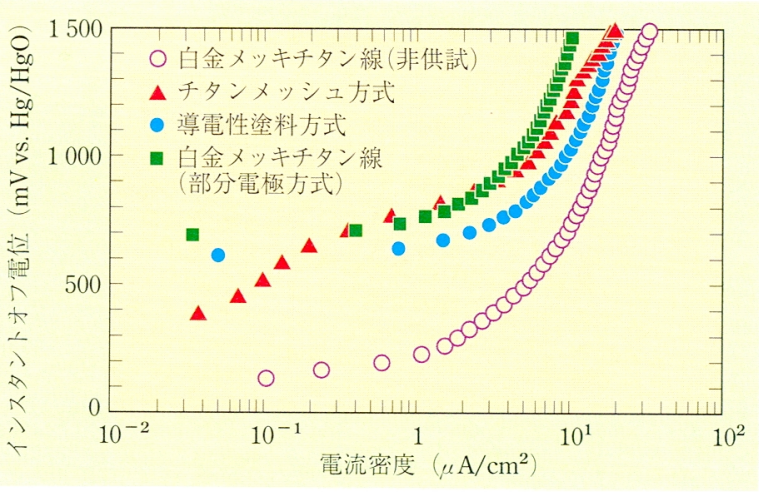

図 3-4 外部電源方式陽極材のアノード分極試験結果
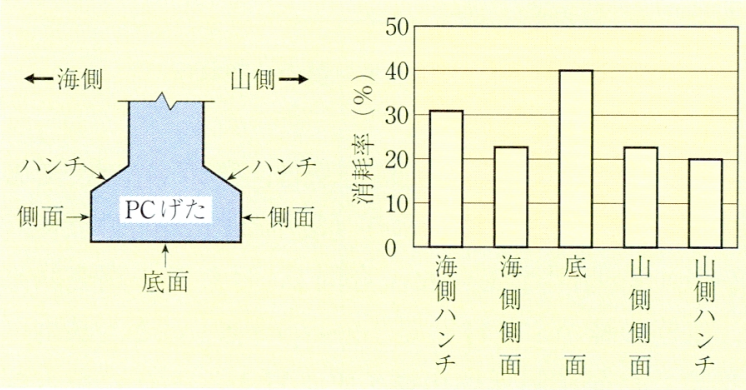

図 3-5 箇所ごとの亜鉛シートの消耗率

は, 多くの電流が必要なことから, 底面, 海側, 山側の 順に発生電流が大きくなり, 陽極である亜鉛シートが消 耗したと考える。

亜鉛シートの底面の消耗状況を写真 -3 に示す。この 写真からも確認できるが, 亜鉛シートは, 均一に消耗せ ず，腐食環境の違いによって，部分的に孔が空いてお り，陽極が寸断され，防食電流が流れなくなることが予 想される。効果的な電気防食を期待する場合, 亜鉛シー 卜の残存率 (1-消耗率) が問題である。おおむね $30 \%$ 以上残存すれば効果があるものと仮定するならば，現在 の亜鉛シートの消耗率から余寿命を算定すると, 今後, 底面で 7 年, 海側で 16 年, 山側 21 年となる。

当橋の流電陽極方式の耐用年数は, $20 \mathrm{~mA} / \mathrm{m}^{2}$ の発 生電流を考慮し, 約 15 年間ですべて消耗するよう設定 していた。最も消耗が激しい底面に着目すると現在 9 年

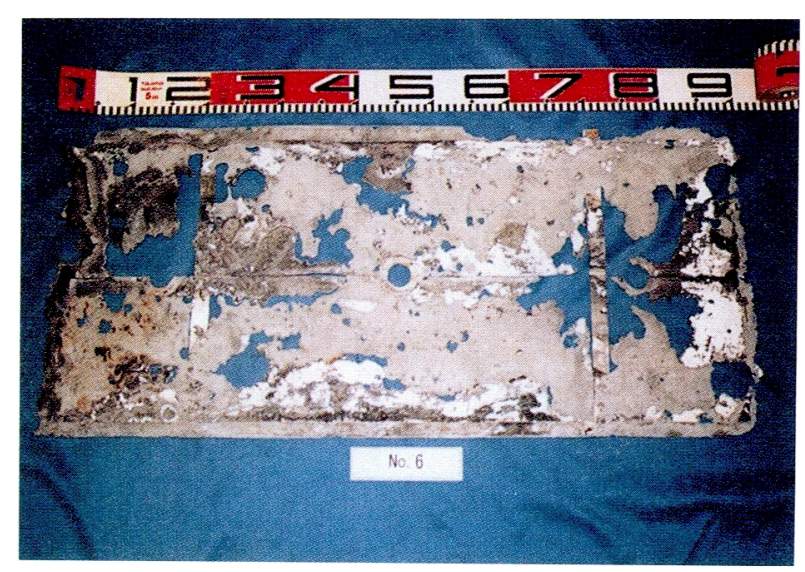

写真-3 底面の覀鉛シートの消耗状況 
経過していることから予寿命を 7 年と推測するならば, ほぼ設定值に近い值となった。

\section{5 コンクリート内部の鋼材腐食状況の確認}

電気防食部および非防食部において，下フランジ底面 の一部をはつり取り, コンクリート内部の鋼材の腐食状 況をブロックごとに確認した。なお，平成元年の電気防 食の工事の際は, 劣化コンクリートを除去し, 鉄筋の錆 落としは第 3 種ケレン程度なので，大部分の鉄筋には本 試験工事以前に発生した錆が残っているもの上推定され る。

\section{（1）電気防食部}

各電気防食部において，コンクリート内部の鋼材の腐 食状況を確認したところ, 電気防食以前に発生したと考 えられる固着性の錆は確認されたが，進行錆は確認され なかった。写真-4は，チタンメッシュ方式におけるコ ンクリート内部の鋼材の状況である。なお，スターラッ プ筋の表面には，電気防食以前に実施された断面修復時 での表面処理工が施されている。

高い含有塩分量の環境においても電気防食を行うこと により，鋼材の腐食の進行は，停止されることが確認さ

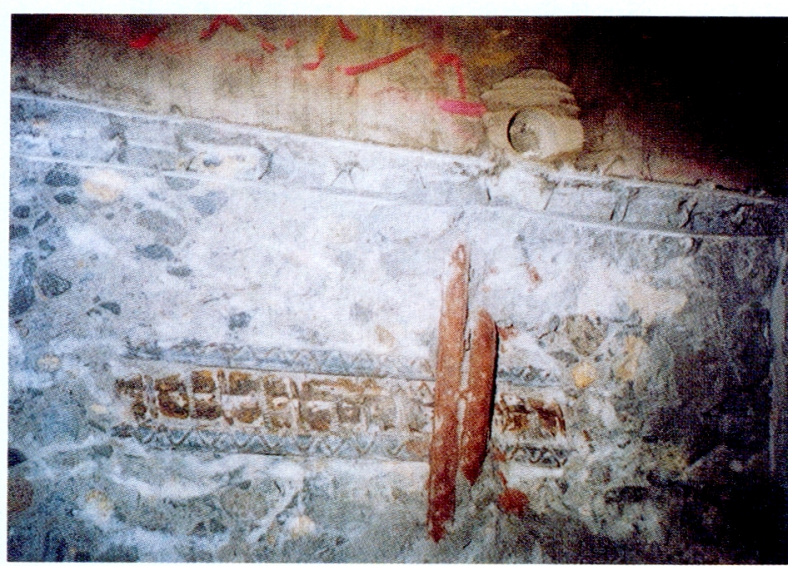

写真-4 チタンメッシュ方式コンクリート内部の鋼材の状況

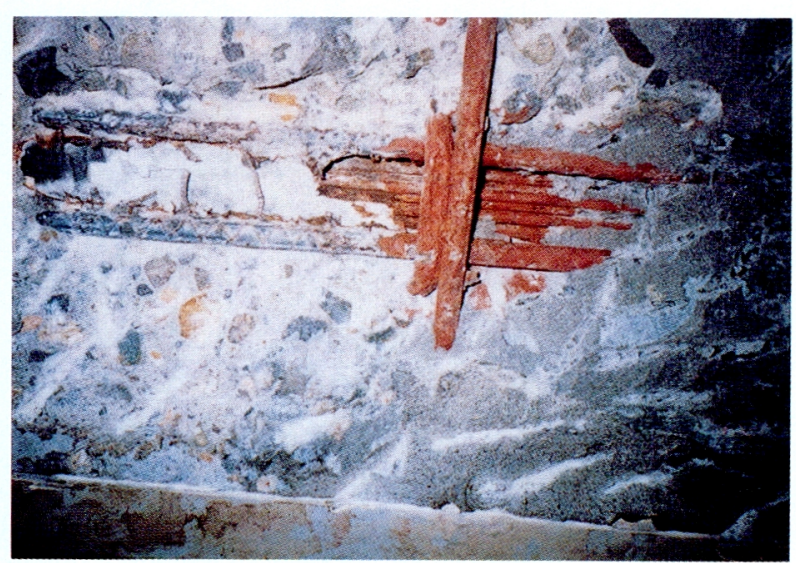

写真 -5 非防食部コンクリート内部の鋼材の発錆状況
れた。

\section{(2) 非防食部}

非防食部では, 過去に断面修復により補修した箇所と 未補修筒所の境界付近で調査を行った。結果は，未補修 部（スターラップ筋の左側）の PC 鋼線に著しい赤錆が 認められた。これは，マクロセル腐食によるものと推定 される（写真 -5$)$

\section{4. まとめ}

大慶寺川橋の 9 年間にわたる電気防食の評価につい て，まとめると以下のとおりである。

(1) 各電気防食とも，9 年間にわたり，所定の復極量 $100 \mathrm{mV}$ を確保することができた。

(2) 外部電源方式では, 年々必要とされる防食電流が 低下し，経済的な電気防食が可能となった。

(3) 流電陽極方式では, 発生電流が年々低下したが, 所定の復極量を確保できた。

(4) 外部電源方式の陽極材 (チタン系) は, 9 年経過 した現在でも全く健全であり，当初計画の耐用年 数 40 年は, 確保できるものと思われる。

（5) 流電陽極方式の陽極材 (亜鉛シート) は, コンク リート内部の鋼材密度ならびに腐食状況によって消 耗率が異なった。おおむね，陽極材の残存率を $30 \%$ までを電気防食可能な限界值と考えるならば，耐用 年数は, 約 15 年と推測される。

(6) コンクリート内部の鋼材は，当該地区の推定発錆 限界塩化物イオン量 $1.2 \mathrm{~kg} / \mathrm{m}^{3}$ を大幅に上回る厳 しい塩害環境下にあった。しかし電気防食を実施し ている䇢所は，その鋼材の腐食の進行が停止してい た。一方，非防食部では過去に断面修復を実施した 筒所と未補修の箇所でマクロセル腐食が進行してい た。

謝 辞 本稿は，長期間にわたる関係者のご尽力によ り実現したものである。調査・分析にご協力頂いた(株)ナ カボーテック等関係各位のご協力に対して深く感謝の意 を記す。

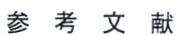

1) (財)高速道路技術センター：北陸自動車道コンクリート構造物塩害 対策検討 (その 3), 1993. 3

2) (社日本コンクリート工学協会 : コンクリート構造物の電気防食工 法研究委員会報告書, pp. 64 70, 1994. 10

3）建設省土木研究所：コンクリート構造物の電気防食工法に関する 共同研究報告書「コンクリート構造物中の電気防食要領(案)」, pp. 90 91, 1988. 8 